This item was submitted to Loughborough's Research Repository by the author.

Items in Figshare are protected by copyright, with all rights reserved, unless otherwise indicated.

\title{
Taxonomic changes and non-native species: An overview of constraints and new challenges for macroinvertebrate-based indices calculation in river ecosystems
}

\section{PLEASE CITE THE PUBLISHED VERSION}

https://doi.org/10.1016/j.scitotenv.2019.01.008

\section{PUBLISHER}

(C) Elsevier

\section{VERSION}

AM (Accepted Manuscript)

\section{PUBLISHER STATEMENT}

This paper was accepted for publication in the journal Science of the Total Environment and the definitive published version is available at https://doi.org/10.1016/j.scitotenv.2019.01.008.

\section{LICENCE}

CC BY-NC-ND 4.0

\section{REPOSITORY RECORD}

Guareschi, Simone, and Paul Wood. 2019. "Taxonomic Changes and Non-native Species: An Overview of Constraints and New Challenges for Macroinvertebrate-based Indices Calculation in River Ecosystems". figshare. https://hdl.handle.net/2134/37107. 
1 Taxonomic changes and non-native species: An overview of constraints and new challenges for macroinvertebrate-based indices calculation in river ecosystems

4 Simone Guareschi ${ }^{*}$, Paul J. Wood ${ }^{2}$

5

$6 \quad{ }^{1}$ Department of Ecology and Hydrology, Regional Campus of International Excellence "Campus Mare 7 Nostrum" University of Murcia, 30100, Spain

*Corresponding author: S. Guareschi simone.guareschi@um.es

13

\section{Highlights}

16

- $\quad$ Biomonitoring tools are required to address new and critical changes to rivers

- Taxonomic constraints and non-native species represent new biomonitoring challenges

- $\quad$ Existing tools need to be flexible so new scientific developments can be integrated policies

Keywords: Bioassessment, alien species, freshwater ecosystems, ecological indicators, 
Abstract

41

Freshwater ecosystems face many threats in the form of reduced water quantity, poor water quality and the loss of biodiversity. As a result, aquatic biomonitoring tools are required to enable the evaluation of these critical changes. Currently, macroinvertebrate-based indices are globally the most widely used biomonitoring tools in fluvial ecosystems. However, very little is known about the potential effects of changes in taxonomic understanding (updating of classification and nomenclature) or the presence of new non-native species for biotic indices calculation. This is especially relevant given that errors, incorrect classification or exclusion of new / updated nomenclature may affect ecological status evaluations and have direct consequences for the management and conservation of freshwater systems. In this discussion paper the main constraints, challenges and implications of these issues are outlined and case studies from a range of European countries are discussed. However, similar challenges affect river and managers globally and will potentially be amplified further in the future. Bioassessment science needs to be open to improvements, and current tools and protocols need to be flexible so that they can be updated and revised rapidly to allow new scientific developments to be integrated. This discussion highlights specific examples and new ideas that may contribute to the future development of aquatic biomonitoring using macroinvertebrates and other faunal and floral groups in riverine ecosystems.

\section{Introduction}

Monitoring freshwater ecosystems is an essential task to fulfil environmental legislation, reflecting attempts to quantify and manage the strong anthropogenic pressures that affect their ecological status. Freshwater biomonitoring is a multidisciplinary field that integrates scientific understanding from different areas of theoretical and applied research, including aquatic ecology, taxonomy, environmental legislation, water resource management and a wide range of stakeholders and end-users (e.g. Nichols et al., 2017). In 
67 Europe, after the implementation of the Water Framework Directive 2000/60/CE 68 (European Commission, 2000), the role of biological indicators (usually called bioindicators) has been elevated due to the prominence they are given as indicators of "ecological status" for aquatic ecosystems. Following the implementation of the EU WFD, ecological status is expressed in five classes based on the EQR (Ecological Quality Ratio). This represents the ratio between a measured biological element recorded in the field in relation to the same parameter under 'reference conditions' (i.e., without anthropogenic pressures) within the same ecosystem type. Aquatic macroinvertebrates have a longstanding tradition of being used as effective biological indicators of aquatic ecosystems since the early 1900s (Rosenberg and Resh, 1993) and represent the most widely used elements (bioindicators) to characterise and quantify river system conditions (Bonada et al., 2006; Buss et al., 2015). The macroinvertebrate community-based indices currently used in Europe were primarily developed at the end of the Twentieth and beginning of the Twenty-First Century. In response to the EU WFD 2000/60/CE, some European countries, such as France, Italy, and Belgium, replaced their exiting biomonitoring tools with new multi-metric indices and/or new procedures (Buffagni et al., 2006; Buffagni and Erba, 2007; Gabriels et al., 2010; Mondy et al., 2012). However, other countries such as Spain and the UK maintained a connection with pre-existing indices by transforming and improving preWFD methods (Munné and Prat, 2009; UKTAG 2014; Bo et al., 2017).

During contemporary routine aquatic biomonitoring activities (collecting field samples and processing material in the laboratory), recording multiple non-native invertebrate taxa may be common. The introduction of non-native invasive species is one of biggest threats to aquatic ecosystems globally and represents a growing challenge for environmental regulatory authorities (Havel et al., 2015). Human activities are increasingly affecting the spatial distribution of species both directly and unintentionally (Strayer 2010; Paillex et al., 2009; Lovas-Kiss et al., 2018). Furthermore, Jourdan et al. (2018) recently stressed the relevance of changing climate on European stream communities' invasibility - 
referring to the potential increasingly favourable opportunities for non-native and invasive species under many climate change scenarios. Several non-native invasive species have been implicated as being instrumental in modifying native communities (e.g. Simon and Townsend, 2003; Carbonell et al., 2017) with subsequent impacts on freshwater ecosystems (Strayer, 2010; Gallardo et al., 2016; Lovas-Kiss et al., 2018). In most instances, the effects of non-native species on the recipient ecosystem's health have not been fully quantified in the short or medium term as species are not initially identified or recognised as posing a threat, or are not specifically integrated into pre-existing biomonitoring schemes used to assess ecological status (Friberg et al., 2011; Friberg, 2014).

To compound this issue, knowledge regarding the correct taxonomy (at least to family and genus level) for field and laboratory identification purposes is crucial to avoid misclassification of both organisms and waterbody conditions. At the same time, improvements in invertebrate taxonomy have been made due to advances in zoological knowledge and scientific advances, which have provided new information regarding the correct classification of some invertebrates (e.g. Arribas et al., 2013; Saito et al., 2018). Changes in taxonomy have occurred over time and are likely to become increasingly common in the future with advances in new molecular tools facilitating the correct classification of cryptic and less studied invertebrate groups and species complexes which may be morphologically almost identical (e.g., Walther et al., 2010; Macadam et al., 2018; Saito et al., 2018).

Given the long tradition of employing biotic indices and their widespread application in academic research and use by different stakeholders (e.g. private consultants, water resource managers and regulatory authorities), extensive expertise has been developed, especially in Europe and North America (e.g., Reyjol et al., 2014; Bo et al., 2017; Pawlowski et al., 2018). However, many changes have occurred in European freshwater ecosystems since the WFD was first implemented in 2000. This means that current tools 
may not accurately reflect some changes that may have become increasingly common in contemporary systems almost 20-years later (see Table 1).

Given the limitations identified above, both taxonomic constraints and the spread of non-native species represent significant emerging challenges for the application and reliability of riverine biomonitoring activities. This may have consequences for regulatory environmental agencies, water resource managers and others involved in ecological status evaluations. Mis- or incorrect classification could have direct implications for the management and conservation of freshwaters at national and international scales if they are not addressed or recognised during intercalibration or comparison processes among nation states (e.g., WFD Intercalibration processes; Birk and Hering, 2006). There is therefore an urgent need to address some potentially controversial issues and emerging challenges for existing biomonitoring tools. This discussion paper outlines examples associated with constraints due to the science of taxonomy and the potential and realised effects of non-native invasive species from several European countries. We also discuss the potential options available to address these problems with a view to advancing aquatic biomonitoring activities. The primary purpose of this discussion paper is to focus on how changes in taxonomy and the presence of non-native invertebrate species influence biotic index calculations / metrics and their operation rather than the legislative procedures and policy implementation of biomonitoring management frameworks.

\section{Taxonomic constraints and updates}

Many macroinvertebrate-based indices are based on a taxonomic list on which the organisms are grouped and assigned a score based on preferences or tolerances (e.g. a linear scoring system). These lists have typically been approved and validated by an official legislative regulatory authority (government ministry or environmental agency, usually following peer-reviewed publication, e.g. Extence et al. 2013; Chadd et al., 2017) and define 
the taxa and taxonomic resolution to be considered. For example, the Biological Monitoring Working Party (BMWP) score system was widely used in the UK from 1980 as the official macroinvertebrate based biomonitoring of freshwater lotic ecosystems (Hawkes, 1997) until its refinement in 2014 (UKTAG, 2014). Given its ease of application and reliable results, minor modifications or adaptations have been tested and widely applied in countries throughout Europe, North and South America, Africa and Asia (e.g., Paisley et al., 2014; Aschalew and Moog, 2015). The BMWP score and its derivatives represents a single metric index in which each invertebrate family has been given a score from 1 to 10 based on its known tolerances to organic contamination. The final site score being obtained by summing the individual family scores of the different taxa recorded in the sample. One clear example of its wider application has been the IBMWP index, which has specifically been adapted for use on the Iberian Peninsula (Alba-Tercedor et al., 2002). This has become the most widely used macroinvertebrate biomonitoring method in Spain over the last 25 years (CoutoMendoza et al., 2015) and the official index used in national legislative based monitoring (MAGRAMA, 2015).

However, even since the last refinement of the IBMWP faunal list (MAGRAMA, 2013), some taxonomic changes have occurred and still need to be integrated into the index. An examination of the current taxonomic family list highlights the presence of the gastropod family Ancylidae (with a score of 6). New taxonomic developments have resulted in Ancylidae no longer being recognised and species which were part of the family are currently included taxonomically in the family Planorbidae (Bouchet and Rocroi, 2005; Oscoz et al., 2011; Bank, 2013); which obtains an IBMWP score of 3. Given the IBMWP's additive character and sensitivity to low abundance taxa (Guareschi et al., 2017), this could result in elevated final index values and potentially ecological status in some cases. In this instance, advances in taxonomy have moved faster than updates to environmental legislation. This issue is not unique to Spanish waterbodies since Ancylidae at the family level is also present on other taxonomic lists, for example, the multimetric STAR_ICM Index 
174 (ISPRA, 2014 and see Table 1a). This index has been used in Europe as the Intercalibration

175 Common Metric Index, and is the official index currently used in Italy and Cyprus to assess

176 river ecological statuses to fulfil EU WFD legislation (details in Buffagni et al. 2006, Feio et

177 al., 2014, ISPRA 2014). The STAR_ICM index is comprised of 6 metrics: ASPT (Average Score

178 Per Taxon), logarithm of the selected families of Ephemeroptera, Plecoptera, Trichoptera

179 and Diptera $(\log ($ sel_EPTD+1)), total number of taxa, number of EPT taxa, 1 minus the

180 relative abundance of Gastropoda, Oligochaeta and Diptera (1-GOLD) and the Shannon

181 index.

182

The most common Palearctic species of the former Ancylidae family is Ancylus

fluvialitis Müller, 1774, a rheophilic species with ecological and biological traits that are markedly different to most limnophilic Planorbidae, especially in relation to current velocity and dissolved oxygen preferences (Oscoz et al., 2004). Keeping these taxa separate (Ancylus sp. separate from Planorbidae) would appear to be a sensible choice for riverine biomonitoring purposes and one option would be to replace Ancylidae on official lists but to include the genus taxonomic designation - Ancylus. This change has already been applied to the Whalley, Hawkes, Paisley and Trigg Index (WHPT), one of the indices currently used in the UK (UKTAG, 2014) which considers the Ancylus group separately from other members of the family Planorbidae.

Another example is illustrated by the caddisfly species Pseudoneureclipsis lusitanicus Malicky, 1980 that has been recorded in Portugal, Spain and France (González and Martínez, 2011). It was formerly considered part of the family Polycentropodidae but is currently assigned to the family Dipseudopsidae (Tachet et al., 2001) which is not reported or recognised on the official Spanish IBMWP lists. Similarly, Acroloxus Beck, 1838, now belongs to the family Acroloxidae (Gastropoda) and Pediciidae (Diptera, Tipuloidea) are not included as scoring taxa on the IBMWP taxonomic list but, are considered in other European macroinvertebrate indices (e.g., STAR_ICM index and WHPT, Table 1a). 

topic worthy of attention and discussion. The use of a higher taxonomic level for invertebrates (e.g. family) is widely employed for most biomonitoring indices and is considered a good compromise between classification effort and obtaining appropriate biological information (e.g., Gayraud et al., 2003; Monk et al.,2012). A greater taxonomic resolution (genus or species level) may provide additional information but may be extremely time consuming and incur a greater economic cost. For instance, the IBMWP taxa list is composed primarily of taxa at the family level, with a few exceptions for higher taxonomic levels: Acariformes, Oligochaeta and Ostracoda. The other exception concerns the only genus currently included on the IBMWP list: Ferrissia Walker, 1903. The regulatory authority stopped considering Ferrissidae as a separate family in its own right (now incorporated within Planorbidae), but uses the genus: Ferrissia (MAGRAMA, 2013) with a score of 6 . The use of Ferrissia as the only genus currently considered is odd given that little is known scientifically regarding its tolerances, preferences and spatial distribution (Oscoz et al., 2011). Furthermore, the taxonomy of the Palaearctic Ferrissia taxa is currently under debate, and no consensus has been reached on the presence or identity of any true autochthonous Palearctic species (Vecchioni et al., 2017). Moreover, the cryptic invasion by the North American gastropod, Ferrissia fragilis (Tryon, 1863), has been highlighted in Southern Europe ecosystems (Marrone et al., 2011) and in other countries with surprising conservation implications (e.g., invasive species considered endangered freshwater limpets, Saito et al., 2018). Some exceptions regarding the use of genus level data can be found within the biomonitoring tools used across Europe. For example, Buffagni and Erba (2007) stressed the importance of Operational Units (genus and subgenus) to the Order Ephemeroptera for surveillance and investigative monitoring surveys. This has subsequently been integrated into Italian monitoring legislation. Similarly, the Belgian MMIF index, and the I2M2 Index used in France, requires some invertebrate orders to be identified to the genus level 
227 (Gabriels et al. 2010; Mondy et al. 2012). However, in the latter, as well as in the STAR_ICM,

228 taxa belonging to Planorbidae are always recorded at the family level.

Specific research at the genetic level and in relation to experimental tolerances of Ferrissia and its Iberian, and wider European populations, is therefore recommended considering that information regarding the presence of native European or western Mediterranean species is pending. Given current knowledge, a score of 6 for a genus with doubts raised regarding its origin and taxonomy requires reflection. However, a traditional taxonomic approach (although this is also problematic) would still consider it at the family level (Planorbidae - 3 points). Should no new findings regarding the autochthonous Ferrissia be forthcoming, questions regarding whether the genus should be given a score on any European taxonomic list may need to be addressed.

These effects and constraints on multiple national taxonomic lists and family level metrics are common and given that legislation should be responsive to scientific advances, periodic updating and greater flexibility is recommended. Modifications made to taxonomic lists should be confirmed on official documents validated by the national regulatory authority, after careful scientific-technician evaluation of potential consequences, to standardise scoring systems and avoiding inhomogeneity when interpreting data and results.

\section{The role of alien species in river biomonitoring: how should they be considered?}

Although there is a growing body of literature on non-native species, relatively little is known about their effect on routine biomonitoring results or about which metrics could be particularly affected. Some notable exceptions include recent research undertaken in Central Europe and the UK, which has demonstrated how the presence of non-native invasive species may affect the metric scores and even the potential classification of a freshwater body's ecological status (e.g., McNeil et al., 2013, Mathers et al. 2016). 

Mollusca and Crustacea fauna (Fenoglio et al., 2016). The geographical range of non-native invasive bivalves, such as Corbicula fluminea (Müller, 1774), are expanding in many European countries (e.g., Zamora-Marín et al., 2018) but are not typically integrated into existing biomonitoring schemes despite being recognised as a problem in Belgium for interpreting biomonitoring outputs (Gabriels et al., 2005). Other species, such as Dreissena polymorpha (Pallas 1771) (zebra mussel), which are widespread in many waterbodies, may benefit from future climate change in some European areas, but less in others (Gallardo and Aldridge, 2013) with potentially diverse effects on wider communities and ecosystem functioning (Ward and Ricciardi, 2007). to the family Astacidae, a non-tolerant family with relatively high score on both the WHPT and IBMWP lists (scoring 8-10). In this instance, the presence of a non-native taxon (if considered at the family level, see Table1b) could increase the final index value, with potential consequences for the ecological status classification. In the UK, the WHPT index explicitly includes non-native species information when considering Astacidae taxa but utilises the same tolerance values (UKTAG 2014). However, Mathers et al., (2016) found that sites subject to invasion by signal crayfish may experience elevated biotic index scores because of their predation of leeches and snails (typically lower scoring taxa). This means that some sites could theoretically obtain higher index scores as a result of the presence and activities of a non-native species and not because of specific improvements in river ecosystem quality.

In another instance, the Ponto Caspian killer shrimp Dikerogammarus villosus 276 (Sowinsky, 1894), which was recorded in Italy more than 10 years ago (Casellato et al., 277 2006), belongs to the family Gammaridae (occurring on many European taxonomic lists) 278 and would be positively considered in the STAR_ICM index calculation if specific taxonomic 279 information for this species was absent (see Table1b). Similarly, the alien euryhaline corixid 

to river estuary mouths and wetlands (Guareschi et al., 2013), belongs to the same family

282 (Corixidae) as the native species within the genus Sigara Fabricius, 1775, among others. These examples, illustrate how additional taxonomic resolution (e.g., genus level resolution) would provide greater information and if combined with taxonomic updates to national lists avoid the effects of colonisation and invasion being overlooked. Analogous problems may appear with other cryptic taxa, such as some Oligochaeta where multiple families may appear morphologically analogous (e.g., non-native genus Sparganophilus Benham, 1892 and numerous common Lumbricidae taxa, see Rota et al., 2016). The development of specific tools such as DNA metabarcoding could help mitigate, at least partially, some of the issues of reliably identifying species for morphologically similar and cryptic groups (e.g. Pawlowski et al., 2018). highlights multiple issues associated with taxonomic changes and the effects of non-native species on aquatic ecosystems. New molecular studies by Wilke et al. (2013) supported the designation of the species belonging to the family Tateidae (former subfamily of Hydrobiidae, see Batzer and Boix, 2016), but this family is not considered in most European indices. In addition, juvenile life stages of Hydrobiidae (scored family) and Tateidae, such as the native species Mercuria similis (Draparnaud, 1805) and non-native Potamopyrgus antipodarum, could lead to misclassification due to their morphological similarities (Table 1b).

When considering the EQR (Ecological Quality Ratio) and focussing on taxonomic metrics, the presence of non-native invasive species could be considered a shift from the site's reference conditions, or at least a pressure on specific water bodies (ADAS, 2008). However, thus far no official metric exists to characterise the effects of emerging stressors such as non-native taxa in a European WFD context (Hering et al., 2010) or globally. 
macroinvertebrate communities using a site-specific biocontamination index derived from two metrics: an abundance contamination index and a richness contamination index at the ordinal rank. Their research stressed the relevance of biocontamination affecting ecological status assessments using BMWP type methods in Central and Eastern Europe.

Most official biotic indices currently ignore the presence of non-native invasive species or integrate them within the family level designations of native fauna, sometimes without acknowledgement. Non-native species (when detected) are usually reported in the "observations space" of the official field card used by qualified operators when undertaking routine biomonitoring activities. Thanks to this procedure (sometimes not easy for cryptic species), biomonitoring reports could act as an important quantitative resource for research into biodiversity threats, biological invasion(s) and biogeography. This common procedure may be informative but is insufficient given that it has no practical effect on the final index value (e.g. IBMWP Index) and any potential shift in status or functioning is not considered at the ecosystem evaluation stage. In other instances, the taxonomic list used to calculate metrics such as, Average Score Per Taxon (ASPT) and Total Family Richness for the multimetric STAR_ICM Index considers some non-native families such as Corbiculidae and Dreissenidae, despite no BMWP scores currently being available (ISPRA, 2014).

The development of new metrics or modifying existing regulatory methods is beyond the scope of this discussion. However, updates and information from relevant environmental authorities regarding non-native invasive taxa (e.g., a periodically updated list of non-native taxa at a national level potentially with notes on taxonomy, observed tolerances and other faunal associations) would help to avoid overlooking these issues when analysing and interpreting data. Moreover, some flexibility in existing methods and adaptations should be considered. For additive scoring systems such as IBMWP (and numerous other BMWP derived approaches), applying a negative score to each non-native taxon or a generic negative score if non-native taxa are observed in the sample may be an option worthy of further research. Another possibility that may require further research is 
an adaptive attribution of the family level scores: if non-native species are present then a revised score could be use (ideally integrating both native and non-native species tolerance and relevant abiotic / biotic information). However, if no non-native species occur the original score should be used in an unmodified form. In both instances this requires a good species level knowledge of non-native species present in a given country / river basin. In addition, regular updating of lists of non-native aquatic species and new records of recently invaded sites may be crucial for effective management. The same constraints that affect additive scores occur in other commonly used multimetric indices that incorporate an average score / ASPT approach as a core metric (e.g. Cyprus, Italy, Portugal, UK; Feio et al. 2014; UKTAG 2014; Laini et al., 2018). The ASPT and WHPT ASPT Index (total BMWP or WHPT score / number of familes scored) is a direct derivative of the additive scoring system BMWP (Hawkes, 1997). It would be possible to test the effect of a zero score(s) for nonnative families on the final metric. In this way, the effect of non-native taxa could be integrated (e.g., the ASPT or WHPT ASPT value would be lower as the denominator value would increase).

Similar limitations affect macrophyte-based indices like the IBMR (Macrophyte Biological Index for Rivers, Haury et al. 2006) developed in France, but adapted and used in Spain and Italy. The presence of non-native taxa does not affect the final scores in most instances, except for three taxa: Azolla filiculoides Lam, Elodea canadensis Michx and Elodea nuttalii (Planchon) St John, which have been included in the French and Italian scoring systems with their tolerance values. In the case of macrophytes, congeneric species (native and non-native) or cryptic species represent an ongoing challenge to scoring systems (e.g. Ceschin et al., 2016). Fish-based methods for rivers and lakes have a longer tradition of dealing with non-native taxa (Birk et al., 2012) and negative values have been proposed in some biomonitoring systems such as the NISECI Index (Macchio et al., 2017) used in Italy, or the German FIBS (Diekmann et al., 2005), where the occurrence of non-native or hybrid species are penalised in the index final score. 

impacts) and should not necessarily all be treated with the same negative score. Depending on their success in receipt systems, some may have a strong effect on ecosystems by becoming "invasive", whereas others do not represent any clear pattern of effects or may simply occur sporadically (e.g., depending on the waterbody or geographic areas, see examples of Menetus dilatatus (Gould, 1841) or Potamopyrgus antipodarum, Múrria et al., 2008). Could we use some (or all) non-native species to evaluate river ecological status or derive other biotic indexes? Could a river supporting and inhabited by only non-native species be evaluated? Information regarding non-native species' tolerance to anthropogenic pressures or pollution remains scarce for many taxa. It should be investigated, and even incorporated into biomonitoring research, by considering that some non-native species may have similar tolerances to indigenous native species. This would provide ecosystem information when comparable native taxa are missing (see Lagrue et al., 2014) and nonnative taxa could also be assigned an indicator value in their own right for some stressors or conditions, but it may bring into question the EQR and reference conditions (especially in an European WFD context). Another option would be to develop and test metrics specifically to assess the introduction/invasion of non-native taxa (e.g. Arbačiauskas et al., 2008). These new tools should be integrated into the toolbox available to environmental managers and should deal with specific intercalibration procedures if they are intended to complement ecological status evaluation.

The issue of community dominance appears more complicated, in lowland or moderate altitude rivers, where some non-native species may represent the most common taxa in terms of abundance (no. of individuals) or biomass, making it more difficult to correctly apply current biomonitoring indices. For instance, Arndt et al. (2009) showed that the dominance of non-native species may affect the reliability and interpretations of the GSI

386 (German Saprobic Index) results given reduced native macroinvertebrate abundance. 
not integrated into the final score of biomonitoring indices; remaining an open topic of discussion in bioassessment science and ecological research (e.g., Arbačiauskas et al. 2008; Catford et al., 2012).

It is worth highlighting that, despite not being specifically designed for non-native taxa, some metrics like Evenness, the Shannon Index and 1 minus the relative abundance of Gastropoda, Oligochaeta and Diptera (called "1-GOLD"), which are abundance-based metrics sensitive to high densities of individuals, can reflect the dominance of some taxa in the final metric value. Thus the 1-GOLD metric would decrease if there was a high dominance associated with Gastropoda, Oligochaeta and Diptera families. Unfortunately, the taxonomic resolution at the family level would not allow the identification of some nonnative taxa belonging to other groups (e.g., the case of some Crustacean taxa). However, in other instances the opposite scenario may also occur and, paradoxically, this metric would give high values (close to 1) for the low abundances of Gastropoda, Oligochaeta and Diptera, but a very high abundance for taxa from other families, with the consequent risk of "hidden" dominant invasive taxa (in abundance terms) possibly raising the final metric value.

\section{Conclusions}

Aquatic ecosystems face ongoing global challenges due to global environmental change, new non-native/invader taxa, biodiversity loss and hydrological regime modification, and these pressures will affect the results of aquatic biomonitoring. Bioassessement science needs to be open to improvements, and current tools should be flexible so that new scientific advances can be integrated (from not only molecular /genetic perspectives, but also associated with taxonomic, biogeographic, hydro-morphologic and non-native species management advances). For the indices based on the BMWP score / ASPT type metrics, there are specific adjustments that could lead to improved characterisation of waterbody status following wider testing of large datasets. Taxonomic lists of single and multimetric biotic indices should not be considered fixed but should be 
415 periodically reviewed (e.g., regularly adapted in the regulatory context of European WFD

416 survey networks) to update and consider possible taxonomic modifications associated with

417 new non-native taxa/invaders. At the European scale, updating and refining taxonomic lists

418 should ideally be accompanied by updating reference condition values and thresholds

419 among ecological classes to allow direct comparison with historical data series. The latter

420 wouldn't be an easy task, but considering that European intercalibration relies on at least

421 partially outdated data (e.g., Birk and Hering, 2006) and that significant changes have

422 occurred within freshwaters over the last 20 years (e.g. new aquatic invaders, taxonomic

423 changes, climatic and hydrological pressures) revised and validated updates would refine

424 and improve bioassessment accuracy of river ecosystems.

Solving these common constraints may bring positive consequences to functional diversity assessments (e.g., updated information on non-native species' functional traits or tolerances would be useful), which could complement bioassessment alongside other WFDcompliant tools (Reyjol et al. 2014). It seems crucial to address the challenges outlined above because mismatches in ecological status classifications may directly affect management and conservation policies and the future conservation status of freshwater ecosystems. Both challenges, in addition to other global freshwater challenges, may allow us to reflect on the potential to improve the family level approach that often hides or ignores taxonomic issues, especially where non-native and native taxa occur in the same family. Similarly, the potential advantages of multimetric indices over single metric indices should also be considered; this topic has already been subject of debate in some instances (e.g. Couto-Mendoza et al., 2015). To avoid criticisms associated with scoring systems limited to faunal tolerances in relation to a single parameter (a common criticism of the BMWP approach which focuses on organic contamination), a multimetric approach would facilitate the assessment of multiple stressors (e.g., potentially including the presence and impacts of new invaders). However, the "core metrics" that compose any multimetric tool should be complementary and assessed each in turn to understand which directly responds to specific 
conditions. The focus just on the final multimetric score may overlook or ignore information

443 that may be apparent when considering the individual components. For example, Meier et

444 al., (2006) proposed the use of 3 different modules to characterising biotic response to: i) organic pollution, ii) general degradation, and iii) acidification in German rivers. These are derived independently (with specific biotic metrics) and subsequently integrated in final evaluation stage to provide a reliable multimetric.

Given the intrinsic multidisciplinary character of biomonitoring, discussion and possible adjustments need to be shared with all "freshwater science" stakeholders, including researchers and practitioners in universities, research centres, government agencies, environmental managers and private consultancies, which deal and work with these issues on a daily basis. Finally, the next generation of genetic sequencing approaches (e.g., DNA metabarcoding) appear to be on the brink of revolutionising ecology and there are strong opportunities to complement and improve aquatic bioassessment methods at least for presence/absence data of most macronvertebrate groups (e.g., Elbrecht \& Leese, 2017; Pawlowski et al., 2018). However, these new tools should also provide a bridge between the past and the present by allowing the comprehensive use of long-term data series.

\section{Acknowledgements}

Authors would like to thank J.M. Tierno de Figueroa, A. Laini, A. Millán, D. SánchezFernández, M.M. Sánchez-Montoya, F. Marrone, R. Martinez-García, A. Mellado and R. Bolpagni who provided useful comments in a preliminary draft of the manuscript. Thanks also to the constructive inputs provided by anonymous reviewers and the associate editor. 
ADAS. (2008). Alien species and the Water Framework Directive: using alien species forums to address problems in Scottish catchments. Scottish Natural Heritage Commissioned Report No.299 (ROAME No. R07AC614).

474

Alba Tercedor, J., Jáimez-Cuéllar, P., Álvarez, M., Avilés, J., Bonada, N., Casas, J, Mellado, A., 476 Ortega, M., Pardo, I., Prat, N., Rieradevall, M., Robles, S., Sáinz Cantero, C.E., Sánchez-Ortega, del estado ecológico de ríos mediterráneos ibéricos mediante el índice IBMWP (antes BMWP'). Limnetica, 21, 175-185.

480

Arbačiauskas, K., Semenchenko, V., Grabowski, M., Leuven, R. S., Paunović, M., Son, M. O.,

Csányi, B., Gumuliauskaitė, S., Konopacka, A., Nehring, S., van der Velde, G., Vezhnovetz, V., Panov, V.E., 2008. Assessment of biocontamination of benthic macroinvertebrate communities in European inland waterways. Aquatic Invasions, 3, 211-230.

Arndt, E., Fiedler, S., \& Böhme, D., 2009. Effects of invasive benthic macroinvertebrates on assessment methods of the EU Water Frame Work Directive. Hydrobiologia, 635, 309-320.

488

Arribas, P., Andújar, C., Sánchez-Fernández, D., Abellán, P., \& Millán, A., 2013. Integrative 490 taxonomy and conservation of cryptic beetles in the Mediterranean region (Hydrophilidae). Zoologica Scripta, 42, 182-200.

Aschalew, L., \& Moog, 0., 2015. Benthic macroinvertebrates based new biotic score 494 "ETHbios" for assessing ecological conditions of highland streams and rivers in Ethiopia. Limnologica-Ecology and Management of Inland Waters, 52, 11-19. 
497 Bank, H., 2013. Fauna Europaea: Gastropoda. Fauna Europaea version 2017.06 available at https://fauna-eu.org

499

500 Batzer, D., \& Boix, D., 2016. Invertebrates in Freshwater Wetlands: An International 501 Perspective on their Ecology. Springer International Publishing Switzerland ISBN 978-3502 319-24976-6.

503

504

Birk, S., \& Hering, D. (2006). Direct comparison of assessment methods using benthic 505 macroinvertebrates: a contribution to the EU Water Framework Directive intercalibration exercise. Hydrobiologia, 566, 401-415.

507

Birk, S., Bonne, W., Borja, A., Brucet, S., Courrat, A., Poikane, S., Solimini, A., Van De Bund, W., Zampoukas, N. and Hering, D., 2012. Three hundred ways to assess Europe's surface waters: an almost complete overview of biological methods to implement the Water Framework Directive. Ecological Indicators, 18, 31-41.

512

Bo, T., Doretto, A., Laini, A., Bona, F., \& Fenoglio, S., 2017. Biomonitoring with macroinvertebrate communities in Italy: what happened to our past and what is the future? Journal of Limnology, 76, 21-28.

516

517 Bonada, N., Prat, N., Resh, V. H., \& Statzner, B., 2006. Developments in aquatic insect biomonitoring: a comparative analysis of recent approaches. Annu. Rev. Entomol., 51, 495523.

521 Bouchet, P., and J. P. Rocroi. 2005. Classification and nomenclature of gastropod families. International Journal of Malacology, 47, 1-397 
524 Buffagni, A., S. Erba, M. Cazzola, J. Múrria-Bligh, H. Soszka \& P. Genomi, 2006. The STAR 525 common metrics approach to the WFD intercalibration process: full application for small, 526 lowland rivers in three European countries. Hydrobiologia, 566, 379-399.

527

528 Buffagni A, Erba S, 2007. Macroinvertebrati acquatici e Direttiva 2000/60/EC (WFD) Parte

529 A. Metodo di campionamento per i fiumi guadabili. Article in Italian. IRSA-CNR Notiziario 530 dei metodi analitici 1, 1-27. Report in Italian.

531

532

Buss, D. F., Carlisle, D. M., Chon, T. S., Culp, J., Harding, J. S., Keizer-Vlek, H. E., Robinson, W.A.,

Strachan, S., Thirion, C., Hughes, R.M., 2015. Stream biomonitoring using macroinvertebrates around the globe: a comparison of large-scale programs. Environmental Monitoring and Assessment, 187, 4132.

536

537 Carbonell, J. A., Velasco, J., Millán, A., Green, A. J., Coccia, C., Guareschi, S., \& Gutiérrez538 Cánovas, C., 2017. Biological invasion modifies the co-occurrence patterns of insects along a stress gradient. Functional Ecology, 31, 1957-1968.

540

541 Casellato, S., Piana, G. L., Latella, L., \& Ruffo, S., 2006. Dikerogammarus villosus (Sowinsky, 542 1894) (Crustacea, Amphipoda, Gammaridae) for the first time in Italy. Italian Journal of Zoology, 73, 97-104.

544

545

Catford, J. A., Vesk, P. A., Richardson, D. M., \& Pyšek, P. (2012). Quantifying levels of biological 546 invasion: towards the objective classification of invaded and invasible ecosystems. Global 547 Change Biology, 18, 44-62. 
550 Kunth, an alien species often mistaken for the native L. minor L. (Araceae). Aquatic Botany, $551 \quad 131,51-56$

552

553 Chadd, R. P., England, J. A., Constable, D., Dunbar, M. J., Extence, C. A., Leeming, D. J., ... \& 554 Wood, P. J., 2017. An index to track the ecological effects of drought development and 555 recovery on riverine invertebrate communities. Ecological Indicators, 82, 344-356

556

557 Couto-Mendoza, M. T., Vieira-Lanero, R., \& Cobo, F., 2015. More complexity does not always mean more accuracy: the case of IBMWP and METI in NW Spain. Ecohydrology, 8, 595-609.

Diekmann, M., U. Dußling \& R. Berg, 2005. Handbuch zum fischbasierten Bewertungssystem für Fließgewässer (FIBS). Fischereiforschungsstelle Baden-Württemberg, Langenargen. Report in German.

563

Elbrecht, V. \& Leese, F. (2017). Validation and development of COI metabarcoding primers for freshwater macroinvertebrate bioassessment. Frontiers in Environmental Science 5, 11

566

567 European Commission (2000) Directive 2000/60/EC of the European Parliament of the 568 Council of 23rd October 2000 establishing a framework for community action in the field of water policy. Official Journal of the European Communities, L327, 1-72.

570

571 Extence, C.A.; Chadd, R.P; England, J.; Dunbar, M,J.; Wood, P.J; \& Taylor, D.E., 2013. The assessment of fine sediment accumulation in rivers using macro-invertebrate community response. River Research and Applications, 29(1), 17-55. 
575 Feio, M. J., Ferreira, J., Buffagni, A., Erba, S., Dörflinger, G., Ferréol, M., Munné, A., Prat N., 576 Tziortzis, I., Urbanič, G., 2014. Comparability of ecological quality boundaries in the

577 Mediterranean basin using freshwater benthic invertebrates. Statistical options and 578 implications. Science of the Total Environment, 476, 777-784.

579

580 Fenoglio, S., Bonada, N., Guareschi, S., López-Rodríguez, M. J., Millán, A., \& de Figueroa, J. M.

581 T., 2016. Freshwater ecosystems and aquatic insects: a paradox in biological invasions. 582 Biology letters, 12, 20151075.

583

584

Friberg, N., Bonada, N., Bradley, D. C., Dunbar, M. J., Edwards, F. K., Grey, J., Hayes RB, Hildrew

AG, Lamouroux N., Trimmer M., \& Woodward, G. U. Y., 2011. Biomonitoring of human impacts in freshwater ecosystems: the good, the bad and the ugly. Advances in Ecological Research, 44, 1-68.

588

Friberg 2014. WIREs Water 2014. doi:10.1002/wat2.1040

590

591 Gabriels W, Goethals PLM, De Pauw N, 2005. Implications of taxonomic modifications and 592 alien species on biological water quality assessment as exemplified by the Belgian Biotic Index method. Hydrobiologia, 542, 137-150.

594

Gabriels, W., Lock, K., De Pauw, N., \& Goethals, P. L., 2010. Multimetric Macroinvertebrate 596 Index Flanders (MMIF) for biological assessment of rivers and lakes in Flanders (Belgium). Limnologica-Ecology and Management of Inland Waters, 40, 199-207.

Gallardo, B., \& Aldridge, D.C., 2013. Evaluating the combined threat of climate change and biological invasions on endangered species. Biological Conservation, 160, 225-233. 
602

603

604

605

606

607

608

609

610

611

612

613

614

615

616

617

618

619

620

621

622

623

624

625

626

627

628

Gallardo, B., Clavero, M., Sánchez, M. I., \& Vilà, M., 2016. Global ecological impacts of invasive species in aquatic ecosystems. Global change biology, 22, 151-163.

Gayraud, S., Statzner, B., Bady, P., Haybachp, A., Schöll, F., Usseglio-Polatera, P., \& Bacchi, M. 2003. Invertebrate traits for the biomonitoring of large European rivers: an initial assessment of alternative metrics. Freshwater Biology, 48, 2045-2064.

González, M. A., \& Martínez, J., 2011. Checklist of the caddisflies of the Iberian Peninsula and Balearic Islands (Trichoptera). Zoosymposia, 5, 115-135

Guareschi, S., Coccia, C., Sánchez-Fernández, D., Carbonell, J.A., Velasco, J., Boyero, L., Green, A.J. and Millán, A., 2013. How far could the alien boatman Trichocorixa verticalis verticalis spread? Worldwide estimation of its current and future potential distribution. PLoS One, 8(3), e59757.

Guareschi, S., Laini, A., Sánchez-Montoya, M.M., 2017. How do low-abundance taxa affect river biomonitoring? Exploring the response of different macroinvertebrate-based indices. Journal of Limnology, 76, 9-20.

Havel, J. E., Kovalenko, K. E., Thomaz, S. M., Amalfitano, S., \& Kats, L. B., 2015. Aquatic invasive species: challenges for the future. Hydrobiologia, 750, 147-170.

Hawkes, H.A., 1997. Origin and development of the Biological Monitoring Working Party score system. Water Research, 32, 964 - 968.

Hering, D., Borja, A., Carstensen, J., Carvalho, L., Elliott, M., Feld, C.K., Heiskanen, A.S., Johnson, R.K., Moe, J., Pont, D. and Solheim, A.L., van de Bund, W., 2010. The European Water 
629 Framework Directive at the age of 10: a critical review of the achievements with 630 recommendations for the future. Science of the Total Environment, 408, 4007-4019.

631

632 ISPRA, 2014. Linee guida per la valutazione della componente macrobentonica fluviale ai 633 sensi del DM 260/2010, ISPRA Istituto Superiore per la Protezione e Ricerca Ambientale. 634 Manuali e Linee Guida 107/2014. 99 pp. Report in Italian.

635

Jourdan, J., O'Hara, R.B., Bottarin, R., Huttunen, K.L., Kuemmerlen, M., Monteith, D., Muotka,

T., Ozoliņ̌š, D., Paavola, R., Pilotto, F. Springe, G., Skuja A., Sundermann A., Tonkin J.D., Haase

P., 2018. Effects of changing climate on European stream invertebrate communities: a long-term data analysis. Science of the Total Environment, 621, 588-599.

640

641 Lagrue, C., Podgorniak, T., Lecerf, A., \& Bollache, L. (2014). An invasive species may be better 642 than none: invasive signal and native noble crayfish have similar community effects. Freshwater Biology, 59, 1982-1995.

644

Laini, A., Bolpagni, R., Cancellario, T., Guareschi, S., Racchetti, E., \& Viaroli, P., 2018. Testing the response of macroinvertebrate communities and biomonitoring indices under multiple stressors in a lowland regulated river. Ecological Indicators, 90, 47-53.

648

649

Kołodziejczyk, A., \& LewAndowsKi, K. (2015). A new record of an alien species, trumpet 650 ram's-horn, Menetus dilatatus (Gould, 1841)(Gastropoda: Planorbidae) in Poland. Folia Malacologica, 23(2).

652

Lovas-Kiss, Á., Sánchez, M. I., Molnár V, A., Valls, L., Armengol, X., Mesquita-Joanes, F., \& 654 Green, A. J., 2018. Crayfish invasion facilitates dispersal of plants and invertebrates by gulls. Freshwater Biology, 63, 392-404. 
657 Macadam, C. R., Chadd, R. P., Pickwell, A., \& Doe, J. 2018. A new British mayfly: Baetis 658 atlanticus (Soldán \& Godunko, 2006)(Ephemeroptera: Baetidae). Entomologist's Monthly 659 Magazine, 154(4), 263-265.

660

661

Meier, C.; Böhmer, J.; Biss, R.; Feld, C.; Haase, P.; Lorenz, A.; Rawer-Jost, C.; Rolauffs, P.; 662

Schindehütte, K.; Schöll, F.; Sundermann, A.; Zenker, A.; Hering, D., 2006. Weiterentwicklung 663

und Anpassung des nationalen Bewertungssystems für Makrozoobenthos an neue 664 internationale Vorgaben. Im Auftrag des Umweltbundesamtes. Report in German (Abstract 665 available in English).

666

667

Macchio, S., Rossi, G.L., Rossi, G., De Bonis, S., Balzamo, S., Martone, C., 2017. Nuovo indice 668 dello stato ecologico delle comunitá ittiche (NISECI). ISPRA, Manuali e Linee Guida 159/2017. 21pp. Report in Italian.

670

671

MAGRAMA, 2013. Protocolo de cálculo del índice IBMWP. Código: IBMWP-2013. Ministerio

672 de Agricultura, Alimentación y Medio Ambiente, Madrid, Spain. Report in Spanish.

673

674

MAGRAMA, 2015. Criterios de seguimiento y evaluación del estado de las aguas 675 superficiales y las normas de calidad ambiental. Boletín Oficial del Estado-BOE, 219: 80582-

676 80677. Ministerio de Agricultura, Alimentación y Medio Ambiente, Madrid, Spain. Report in

677 Spanish.

678

679 Mathers, K. L., Chadd, R. P., Extence, C. A., Rice, S. P., \& Wood, P. J., 2016. The implications of 680 an invasive species on the reliability of macroinvertebrate biomonitoring tools used in 681 freshwater ecological assessments. Ecological Indicators, 63, 23-28. 
686

687

688

689

690

691

692

693

694

695

696

697

698

699

700

701

702

703

704

705

706

707

708

709

Marrone, F., Brutto, S., \& Arculeo, M., 2011. Cryptic invasion in Southern Europe: the case of Ferrissia fragilis (Pulmonata: Ancylidae) Mediterranean populations. Biologia, 66(3), 484490.

MacNeil, C., Boets, P., Lock, K., \& Goethals, P. L., 2013. Potential effects of the invasive 'killer shrimp' (Dikerogammarus villosus) on macroinvertebrate assemblages and biomonitoring indices. Freshwater Biology, 58, 171-182.

Mondy, C. P., Villeneuve, B., Archaimbault, V., \& Usseglio-Polatera, P., 2012. A new macroinvertebrate-based multimetric index (I2M2) to evaluate ecological quality of French wadeable streams fulfilling the WFD demands: A taxonomical and trait approach. Ecological Indicators, 18, 452-467.

Monk, W.A., Wood, P.J., Hannah, D.M., Extence, C.A., Chadd, R.P. \& Dunbar, M.J. 2012. How does macroinvertebrate taxonomic resolution influence ecohydrological relationships in riverine ecosystems. Ecohydrology, 5, 36-45.

Munné, A., \& Prat, N., 2009. Use of macroinvertebrate-based multimetric indices for water quality evaluation in Spanish Mediterranean rivers: an intercalibration approach with the IBMWP index. Hydrobiologia, 628, 203.

Múrria, C., Bonada, N., \& Prat, N., 2008. Effects of the invasive species Potamopyrgus antipodarum (Hydrobiidae, Mollusca) on community structure in a small Mediterranean stream. Fundamental and Applied Limnology/Archiv für Hydrobiologie, 171, 131-143.

Nichols, S. J., Barmuta, L. A., Chessman, B. C., Davies, P. E., Dyer, F. J., Harrison, E. T., Hawkins, C. P., Jones, I., Kefford, B. J., Linke, S., Marchant, R., Metzeling, L., Moon, K., Ogden, R., Peat, M., 
710 Reynoldson, T. B., and Thompson, R. M. (2017). The imperative need for nationally

711 coordinated bioassessment of rivers and streams. Marine and Freshwater Research, 68, $712 \quad 599-613$.

713

714 Oscoz, J., Durán, C., \& Larraz, M. L., 2004. Contribución al conocimiento de algunos moluscos acuáticos (Mollusca: Gastropoda) en la cuenca del Ebro. Munibe, 55, 155-166.

716

717 Oscoz J., Galicia D., Miranda R., 2011. Identification Guide of Freshwater Macroinvertebrates of Spain. Springer, Dordrecht, 173 pp.

719

720 connectivity. Journal of Applied Ecology, 46, 250-258.

Paisley, M. F., Trigg, D. J., \& Walley, W. J., 2014. Revision of the biological monitoring working party (BMWP) score system: derivation of present-only and abundance-related scores from field data. River research and applications, 30, 887-904.

727

Pawlowski, J., Kelly-Quinn, M., Altermatt, F., Apothéloz-Perret-Gentil, L., Beja, P., Boggero, A., Borja, A., Bouchez, A., Cordier, T., Domaizon, I., Feio, M.J., Filipe, A.F., Fornaroli, R., Graf, W., Herder, J., van der Hoorn, B., Jones, J.I., Sagova-Mareckova, M., Moritz, C., Barquín, J. Piggott, J.J., Pinna, M., Rimet, F., Rinkevich, B., Sousa-Santos, C., Specchia, V., Trobajo, R., Vasselon, V., Vitecek, S., Zimmerman, J., Weigand, A., Leese, F., Kahlert, M., 2018. The future of biotic indices in the ecogenomic era: Integrating (e) DNA metabarcoding in biological assessment of aquatic ecosystems. Science of the Total Environment, 637, 1295-1310 
Reyjol, Y., Argillier, C., Bonne, W., Borja, A., Buijse, A.D., Cardoso, A.C., Daufresne, M., Kernan,

737 M., Ferreira, M.T., Poikane, S., Prat, N., Solheim A.L., Stroffek, S., Usseglio-Polatera, P., 738 Villeneuve, B., van de Bund, W., 2014. Assessing the ecological status in the context of the 739 European Water Framework Directive: where do we go now? Science of the Total 740 Environment, 497, 332-344.

741

742 Rosenberg DM, Resh VH, eds. 1993. Freshwater Biomonitoring and Benthic Annu. Rev. Entomol. 2006.51:495-523. Macroinvertebrates. New York: Chapman \& Hall. 488 pp.

744

Rota, E., Bartoli, M., \& Laini, A., 2014. First time in Italy. Is the elusive aquatic megadrile Sparganophilus Benham, 1892 (Annelida, Clitellata) accelerating its dispersal in Europe? Journal of Limnology, 73, 482-489.

Saito, T., Prozorova, L., Hirano, T., Fukuda, H., \& Chiba, S. 2018. Endangered freshwater limpets in Japan are actually alien invasive species. Conservation Genetics, 1-12. https://doi.org/10.1007/s10592-018-1068-5

Simon, K.S. \& Townsend, C.R., 2003. Impacts of freshwater invaders at different levels of ecological organisation, with emphasis on salmonids and ecosystem consequences. Freshwater Biology, 48, 982-994.

756

757

Strayer, D. L., 2010. Alien species in fresh waters: ecological effects, interactions with other stressors, and prospects for the future. Freshwater Biology, 55, 152-174.

Tachet, H., Morse, J. C., \& Berly, A., 2001. The larva and pupa of Pseudoneureclipsis lusitanicus

761 Malicky, 1980 (Trichoptera: Hydropsychoidea): description, ecological data and taxonomical considerations. Aquatic Insects, 23, 93-106. 
764 Tachet H., Richoux P., Bournard M. \& Usseglio-Polatera P. (2010) Invertebres d'eau douce:

765 systematique, biologie, ecologie Paris: CNRS editions.

766

767 Vecchioni, L., Marrone, F., Arculeo, M., \& Arizza, V., 2017. Are there autochthonous Ferrissia

768 (Mollusca: Planorbidae) in the Palaearctic? Molecular evidence of a widespread North

769 American invasion of the Old World. The European Zoological Journal, 84, 411-419

770

771

UKTAG. 2014. UKTAG River Assessment Method, Benthic Invertebrate Fauna. Invertebrates

General Degradation): Whalley, Hawkes, Paisley \& Trigg WHPT. Metric in River Invertebrate

Classification

Tool

RICT.

Online

Available

from:

http://www.wfduk.org/sites/default/files/Media/Characterisation\%20of\%20the\%20wat er\%20environment/Biological\%20Method\%20Statements/River\%20Invertebrates\%20

WHPT\%20UKTAG\%20Method\%20Statement.pdf [Accessed 02 June 2018].

777

Walther, A.C., Burch, J.B., Foighil, D.Ó., 2010. Molecular phylogenetic revision of the freshwater limpet genus Ferrissia (Planorbidae: Ancylinae) in North America yields two species: Ferrissia (Ferrissia) rivularis and Ferrissia (Kincaidilla) fragilis. Malacologia, 53, $25-45$

782

Ward, J. M., \& Ricciardi, A. (2007). Impacts of Dreissena invasions on benthic macroinvertebrate communities: a meta-analysis. Diversity and Distributions, 13, 155-165.

Wilke, T., Haase, M., Hershler, R., Liu, H.P., Misof, B. \& Ponder, W., 2013. Pushing short DNA fragments to the limit: Phylogenetic relationships of 'hydrobioid' gastropods 
790 Zamora-Marín, J. M., Zamora-López, A., Sánchez-Pérez, A., Torralva, M., \& Oliva-Paterna, F. 791 J., 2018. Establecimiento de la almeja asiática Corbicula fluminea (Müller, 1774) en la cuenca 792 del río Segura (SE Península Ibérica). Limnetica, 37, 1-7.

793

794 Table

795

796 Table 1. Summary of the main taxonomic constraints (groups with taxonomic revisions,

797 Table 1a) and non-native taxa that may affect the performance of macroinvertebrate-based 798 indexes (1b). Examples and references are also provided (for further details please see the 799 main text).

800

801 
Table 1. Summary of the main taxonomic constraints (groups with taxonomic revisions, Table 1a) and non-native taxa that may affect the performance of macroinvertebrate-based indexes (1b). Examples and references are also provided (for further details please see the main text).

\section{a. Taxonomic constraints}

\begin{tabular}{|c|c|c|c|c|}
\hline Order & Taxa & $\begin{array}{c}\text { Constraints } \\
\end{array}$ & Example & References \\
\hline Diptera & Pediciidae & $\begin{array}{l}\text { Lack of consensus regarding status of } \\
\text { family }\end{array}$ & $\begin{array}{l}\text { Not considered in IBMWP but } \\
\text { included in STAR_ICM and WHPT }\end{array}$ & $\begin{array}{c}\text { Tachet et al. 2010; } \\
\text { MAGRAMA, 2013; ISPRA, } \\
\text { 2014; UKTAG, 2014 }\end{array}$ \\
\hline Mollusca & Ancylidae & Currently within the family Planorbidae & $\begin{array}{l}\text { Indices not updated to incorporate } \\
\text { change (e.g. IBMWP, STAR_ICM) }\end{array}$ & $\begin{array}{l}\text { Oscoz et al., 2011; Bank, } \\
\text { 2013, MAGRAMA, 2013, } \\
\text { ISPRA, 2014 }\end{array}$ \\
\hline Mollusca & Acroloxidae & Taxonomically recognised family & $\begin{array}{l}\text { Not considered in IBMWP but in } \\
\text { included in STAR_ICM and WHPT }\end{array}$ & $\begin{array}{l}\text { Oscoz et al., 2011; } \\
\text { MAGRAMA, 2013; ISPRA, } \\
\text { 2014; UKTAG, 2014 }\end{array}$ \\
\hline Mollusca & Ferrissia & $\begin{array}{l}\text { Lack of consensus regarding } \\
\text { autochthonous Palaearctic taxa }\end{array}$ & $\begin{array}{c}\text { Considered at the genus level in } \\
\text { one index (IBMWP) }\end{array}$ & $\begin{array}{l}\text { Mondy et al., 2012; } \\
\text { MAGRAMA, 2013; } \\
\text { Vecchioni et al., 2017 }\end{array}$ \\
\hline Trichoptera & Dipseudopsidae & $\begin{array}{l}\text { Formerly considered part of the family } \\
\text { Polycentropodidae }\end{array}$ & $\begin{array}{l}\text { Pseudoneureclipsis lusitanicus and } \\
\text { family Dipseudopsidae not } \\
\text { considered in existing indices }\end{array}$ & $\begin{array}{l}\text { Tachet et al., 2001; } \\
\text { González and Martínez, } \\
\text { 2011; MAGRAMA, } 2013\end{array}$ \\
\hline
\end{tabular}




\section{b. Non-native taxa}

\begin{tabular}{|c|c|c|c|c|}
\hline Order & Taxa & Constraints & Example & References \\
\hline Crustacea & Cambaridae & $\begin{array}{l}\text { Non-native taxa frequently dominant in } \\
\text { terms of biomass where they occur }\end{array}$ & $\begin{array}{l}\text { Not considered in most indices } \\
\text { (e.g. IBMWP) but included in } \\
\text { STAR_ICM }\end{array}$ & $\begin{array}{l}\text { MAGRAMA, 2013; ISPRA, } \\
2014\end{array}$ \\
\hline Crustacea & Astacidae & $\begin{array}{l}\text { Native and non-native species occur } \\
\text { within the same family }\end{array}$ & $\begin{array}{c}\text { Pacifastacus leniusculus and } \\
\text { Austropotamobius pallipes complex }\end{array}$ & Tachet et al., 2010 \\
\hline Crustacea & Gammaridae & $\begin{array}{l}\text { Native and non-native species occur } \\
\text { within the same family }\end{array}$ & $\begin{array}{l}\text { Dikerogammarus } \mathrm{sp} . \text { and } \\
\text { Echinogammarus sp. }\end{array}$ & $\begin{array}{l}\text { Tachet et al., 2010; } \\
\text { Casellato et al., } 2006\end{array}$ \\
\hline Hemiptera & Corixidae & $\begin{array}{l}\text { Native and non-native species occur } \\
\text { within the same family }\end{array}$ & $\begin{array}{l}\text { Native Sigara sp. and non-native } \\
\text { Trichocorixa verticalis }\end{array}$ & Guareschi et al., 2013 \\
\hline Haplotaxida & Sparganophilidae & $\begin{array}{c}\text { Cryptic and less studied invertebrate } \\
\text { Order / Families }\end{array}$ & $\begin{array}{l}\text { Classification (native and non- } \\
\text { native) may be difficult for non- } \\
\text { expert operators }\end{array}$ & Rota et al., 2016 \\
\hline Mollusca & Corbiculidae & $\begin{array}{c}\text { Non-native taxa usually dominant in } \\
\text { terms of biomass and / or densities } \\
\text { where they occur }\end{array}$ & $\begin{array}{l}\text { Not always considered in existing } \\
\text { indices (e.g. IBMWP). When it is, its } \\
\text { presence may increase richness } \\
\text { metrics (e.g. STAR_ICM). May cause } \\
\text { problems with interpreting } \\
\text { outputs (MMIF index) }\end{array}$ & $\begin{array}{l}\text { Gabriels et al., 2005; } \\
\text { MAGRAMA, 2013; } \\
\text { ISPRA, 2014 }\end{array}$ \\
\hline Mollusca & Dreissenidae & $\begin{array}{c}\text { Non-native taxa usually dominant in } \\
\text { terms of biomass and / or densities } \\
\text { where they occur }\end{array}$ & $\begin{array}{l}\text { Not always considered in existing } \\
\text { indices (e.g. IBMWP). When it } \\
\text { occurrs, its presence may increase } \\
\text { richness metrics (e.g. STAR_ICM) }\end{array}$ & $\begin{array}{l}\text { Ward and Ricciardi, 2007; } \\
\text { MAGRAMA, 2013; } \\
\text { ISPRA, 2014 }\end{array}$ \\
\hline Mollusca & Hydrobiidae & $\begin{array}{c}\text { Former subfamily Tateidae raised to } \\
\text { taxonomic family and removed from } \\
\text { Hydrobiidae }\end{array}$ & $\begin{array}{c}\text { Potamopyrgus antipodarum } \\
\text { (Tateidae) and Mercuria similis } \\
\text { (Hydrobiidae) can be confused by } \\
\text { non-expert operators }\end{array}$ & $\begin{array}{l}\text { Wilke et al., 2013; Batzer } \\
\text { and Boix, } 2016\end{array}$ \\
\hline Mollusca & Planorbidae & $\begin{array}{l}\text { Native and non-native species occur } \\
\text { within the same family }\end{array}$ & $\begin{array}{l}\text { North American Menetus dilatatus } \\
\text { and numerous Planorbarius } \\
\text { species }\end{array}$ & $\begin{array}{l}\text { Kołodziejczyk and } \\
\text { Lewandowski (2015) }\end{array}$ \\
\hline
\end{tabular}


